\title{
The Effect of Problem Based Learning Model on Students Science Process Skills
}

\author{
Nurul Hasanah \\ Student of Postgraduate \\ State University Of Medan \\ Medan, Indonesia \\ nh8623032@gmail.com
}

\author{
Hasruddin \\ Lecture of postgraduate \\ State University Of Medan \\ Medan, Indonesia
}

\author{
Anita Yus \\ Lecture of postgraduate \\ State University Of Medan \\ Medan, Indonesia
}

\begin{abstract}
Problem based learning (PBL) models are commonly used to assess students problem solving abilities. However, there are several resistance to PBL syntax that can improve students' science process skills. The purpose of this study was to determine the PBL model of students' science process skills. This study is a quasi experimental research using samplings techniqe, where VA class as experimental class I, VB II as experimental class $\mathrm{II}$, and $\mathrm{VC}$ as control class. Data analysis techniques using covariate analysis (ANACOVA) using by SPSS 23.0 for windows applications and data collection using multiple choice test. Based on hypothesis test with $P<0.05$ then $H_{0}$ is rejected and $H_{a}$ accepted where this means there is significant influence on the application of model PBL with average value is 87.60. Its means that PBL (problem from students) more positively than PBL (problem from teacher 82.95), and direct instruction model (average value 78.60) to the students science process skill.
\end{abstract}

Keywords: Problem Based Learning, Direct Instruction, Science Process Skill

\section{INTRODUCTION}

Science education experts argue that science is seen as a process and product. The facts in the field through observation science only instill theory or material to students only, do not pay attention to the development of processes. If only instill theory, science will not give to products and attitudes like scientists that can be useful for students in their personal and social lives. Based on this description, science should be able to develop both dimensions, science as a process includes the skills and attitudes possessed by scientists to achieve scientific products. This means, the development of skills in this process can foster attitudes like those of scientists to achieve scientific products.

If science contains products and processes, then in teaching students not only to deliver science products, but teachers must train students about scientific activities involving various basic skills found in aspects of science process [6]. Developing skills such as acquisition obtained from a process, students will be able to find and develop their own facts and concepts and foster and develop the attitudes and values demanded. Those skills are the main cogs and a good foundation in the process of discovery and attitude development carried out by students as scientists do [12].

\section{THEORETICAL}

Problem-based learning (PBL) is an influential way for inquiry-based learning in which students use an authentic problem as the context for an in-depth investigation of what they need and what to know. Problem-based learning differs from didactic teaching in that students, faced with a description of new situation or event, are required to define their learning needs and questions in order to achieve understanding of the situation or event. Problem-based learning is an educational approach that challenges students to work cooperatively in groups to seek solutions to real-world problems and to develop skills to become self-directed learners [1].

PBL model, there are several theories that form the basis of the learning model, they are: (1) Meaningful learning theory, David Ausebel distinguishes the characteristics of learning, between meaningful learning and rote laerning. Meaningful learning is the process of learning information that has been obtained is connected or associated with new knowledge and experience that someone found in the learning process. The relationship with PBL in terms of linking new information with the cognitive structure students [10]; (2) Vigotsky theory, intellectual development occurs when individuals face new and challenging experiences and when they try to solve problems that arise. Efforts to gain understanding, individuals try to associate new knowledge with the initial knowledge they already have and then build new understanding. The connection with PBL in this case relates new information to the cognitive structure that has been owned by students through learning activities in social interaction with other friends [7]; (3) Jerome S. Brunner's Learning Theory, the discovery method is a method by which students rediscover, not find a completely new one. Learning discovery in accordance with active knowledge seeking by humans, by itself provides better results, trying alone to find solutions to problems and supported by the accompanying knowledge, and produce truly meaningful knowledge. The connection with the PBL model is the ability of students to find and solve problems or solve problems [7].

According to Anggo [9] science process skills are very important for developing students' understanding in applying scientific concepts and increasing proportion of their learning. Through experiences in learning process skills, students can 
achieve meaningful learning skills in scientific problem solving procedures and apply scientific understanding in daily life. According to Semiawan states that process skills are physical and mental skills associated with the fundamental abilities possessed, mastered and applied in a scientific activity, so that scientists succeed in discovering something new. As it known that science does not only consist of a collection of knowledge or various kinds of facts must be memorized, science also consists of activities or processes using the mind in studying natural phenomena that have not been revealed. Achieve a learning there are certainly a number of indicators that we need to know to achieve the extent to which we can achieve that learning and as a benchmark for success in learning. The indicator of the science process skills are: (1) Observing; (2) classifying; (3) interpreting; (4) predicting; (5) communicating; (6) asking questions; (7) submitting hypotheses; (8) planning experiments; (9) using tools; (10) materials and sources; (11) applying concepts.

As a teacher, must be able to design and choose learning models that are in accordance with the themes and basic competencies that must be mastered by students. The learning model chosen should be adjusted to the circumstances and abilities of students, learning resources, and the carrying capacity of the teacher or school. According to Herman [9] problem-based learning is learning that emphasizes more on student activities and makes students interact more with objects and events so that students gain understanding (constructivism). The formulation of Dutch states that problem based learning (PBL) is an instructional method that challenges students to learn and learn, working with groups to find solutions to real problems. This problem is used to link the curiosity and ability of students' analysis and initiative on the subject matter. PB prepares students to think critically and analytically, and to find and use appropriate learning resources. Problem Based Learning (PBL) has important differences with discovery learning. According to Sanjaya [14] there are several steps taken as stages in learning problem based learning are: (1) Formulating problems; (2) analyzing problems; (3) formulating a hypothesis; (4) collecting data; (5) testing the hypothesis; (6) formulating problem solving.

Direct instruction is a teacher center learning model. According to Sanjaya [14] direct learning models are emphasize process of delivering material verbally from a teacher to a group of students with the intention students can master the subject matter optimally. This model subject matter is delivered directly by educators, and students are not required to find the material. Meanwhile, according to Aunurrahman [3] direct learning model is a learning model where activities are focused on academic activities. In this case, the implementation of direct learning is strictly controlled by the teacher to maximize the use of student learning time. In direct learning there are five very important phases. In this case, the teacher begins learning by explaining the purpose and background of learning. Direct learning syntax is presented in five stages: (1) Delivering goals and preparing students; (2) demonstrating knowledge; (3) guiding training; (4) Check understanding and provide feedback; (5) provide opportunities for advanced training and application.

\section{METHOD OF RESEARCH}

The population in this study were all fifth grade students of SDN 056633 Gebang. The sample in this study was determined by sampling technique, as many as 3 classes from the 3 existing classes namely VA class with a total of 20 students taught with the problem based learning model where the problem comes from the students themselves, VB class with the number of 20 students taught with the problem based learning model where the problem comes from the teacher, and the VC class with the number of 20 students taught by direct instruction model.

This type of research is quasi-experimental research by conducting experiments in the classroom that have been formed before not changing the classroom situation and learning schedule.

\begin{tabular}{|c|c|c|c|}
\hline Kelas & Pretes & Perlakuan & Postes \\
\hline $\mathrm{A}$ & $T_{1}$ & $\mathbf{X}_{1}$ & $T_{1}$ \\
\hline B & $T_{1}$ & $\mathbf{X}_{2}$ & $\mathbf{T}_{1}$ \\
\hline $\mathrm{C}$ & $T_{1}$ & $\mathbf{X}_{3}$ & $T_{1}$ \\
\hline \multicolumn{4}{|c|}{ Explanation } \\
\hline $\mathbf{X}_{1}$ & \multicolumn{3}{|c|}{ : Problem Based Learning (students) } \\
\hline $\mathbf{X}_{2}$ & \multicolumn{3}{|c|}{ : Problem Based Learning (teacher) } \\
\hline $\mathbf{X}_{3}$ & \multicolumn{3}{|c|}{ : Direct instruction } \\
\hline $\mathbf{T}_{1}$ & \multicolumn{3}{|c|}{ : science process skills } \\
\hline
\end{tabular}

The formula used in this validity test is Biserial Point Correlation. To find out the validity of the science process skills test using biserial correlation points, with the following formula:

$$
\mathrm{r}_{\mathrm{pbi}}=\frac{M p-M t}{S D} \sqrt{ } \frac{P}{q}
$$

Data analysis techniques used in this study are descriptive analysis techniques and inferential analysis. The description analysis technique is used to describe the research data including the mean, median, mode, variant of standard deviation, minimum value and maximum value. Inferential analysis techniques are carried out to test the hypothesis of normality and homogeneity. Test the normality of Kalmogorov-Smirnov using SPSS 23 for Windows. Homogeneity test is carried out using the Levens Test approach on the SPSS 23 for Windows program [4].

\section{RESULTS AND DISCUSSION}

The results of the research on the application of problem based learning models (problems of students and teachers), as well as direct instruction learning models (direct learning) for pretest science proes skills can be seen in Table 4.1.

TABLE 2 Descriptive Analysis of Pretest

TABLE 2 Descriptive Analysis of Pretest
\begin{tabular}{|c|c|c|c|c|}
\hline Models & Min & Maks & Mean & $\begin{array}{c}\text { Std. } \\
\text { Deviasi }\end{array}$ \\
\hline
\end{tabular}




\begin{tabular}{|l|l|l|l|l|}
\hline PBL (S) Pretes & 33 & 73 & 45,20 & 10,518 \\
\hline PBL (T)Pretes & 27 & 67 & 45,10 & 11,480 \\
\hline DI_Pretes & 27 & 60 & 43,30 & 11,490 \\
\hline
\end{tabular}

Table 4.1 shows that the value of student pretest in the experimental class I which was taught with the problem based learning model (the problem of the students) the highest score was 73 and the lowest value was 33, while the average value and standard deviation were $45.20 \pm 10,518$. as experimental class II pretest results showed the highest score of 67 and the lowest value of 27 , while for the average value and standard deviation of $45.10 \pm 11.480$, and direct instruction shows the highest pretest results of 60 and the lowest value of 27 , while for the average score and standard deviation is $43.30 \pm 11.490$. To test the normality of pretesting the science process can be seen in Table 4.2. Normal distribution of data in class experimental I with a significant 0.200 which is greater than 0 , 05. Furthermore, for the initial ability of the scientific process skills test in the experimental class II which was taught with a significant 0.74 which is greater than 0.05 and the control significantly amounting to 0.157 which is significantly greater than 0.05 , which means the distribution of data is normally distributed. Whereas for the homogeneity test with Leven's Test obtained significant values of $0.647>0.05$ which means that the initial test of science process skills has a homogeneous variant.

TABLE. 3 Descriptive Analysis of Postes

\begin{tabular}{|l|c|c|c|c|}
\hline \multicolumn{1}{|c|}{ Models } & Min & Maks & Std. Dev & Mean \\
\hline PBL (s) Postes & 73 & 100 & 9,270 & 87,60 \\
\hline PBL (t) Postes & 73 & 100 & 8,338 & 82,95 \\
\hline DI_Postes & 67 & 93 & 8,586 & 78,35 \\
\hline
\end{tabular}

The results of descriptive analysis of the postes of science process skills in the experimental class I by applying the problem based learning model obtained the highest value of 100 and the lowest value of 73 with an average and standard deviation of $87.60 \pm 9.270$. Experimental class II the results of the descriptive analysis obtained the highest value of 100 and the lowest value of 73 and the average value and standard deviation of $82.95 \pm 8.338$. Whereas in the control class (DI) from the results of descriptive analysis obtained the highest value of 93 and the lowest value of 67 with an average and standard deviation of $78.35 \pm 8$ 8.586.After the descriptive analysis is carried out further, the prerequisite test for postscience process skills is the normality test with KalmogorovSmirnov can be seen in Table 4.4.

TABLE 4 Kalmogorov-Smirnov Normality Postes

TABLE 4 Kalmogorov-Smirnov Normality Postes
\begin{tabular}{|l|c|c|}
\hline \multicolumn{1}{|c|}{ Models } & Statistik & Signifikan \\
\hline PBL (s) Postes & 0,170 & 0,133 \\
\hline PBL (t) Postes & 0,186 & 0,067 \\
\hline DI_Postes & 0,183 & 0,076 \\
\hline
\end{tabular}

Distribution of data with normal distribution with a significant value of $0.133>0.05$. In the experimental class II also obtained the distribution of post test data of science process skills with normal distribution with a significant value of $0.067>0.05$ as well as the control class with a significant value of $0.076>0.5$. Where as for the homogeneity test with
Leven's Test obtained a significant value of $0.924>0.05$. The results of data processing research shows that the application of the PBL model (students), PBL (teacher) and direct instruction have a significant influence on students' science process skills SDN 056633 Gebang on Magnet Force subject. Based on the results e average value of students in the experimental class I (students) is equal to 87.60 in the experimental class II (teacher) of 82.95 and in the direct instructional class to 78.35 . The data above shows that the class with problem based learning model (problem of students) has a higher average value compared to other classes. To see more clearly the influence of each learning model can be seen in Figure 4.4.

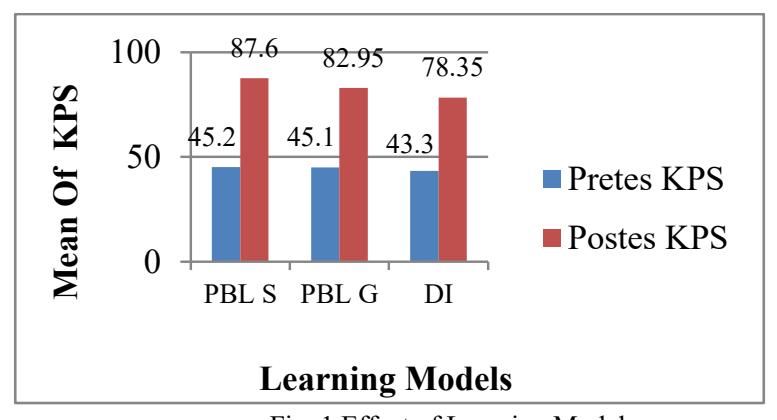

Fig 1 Effect of Learning Models

This means that the science process skills of students who are taught with the problem based learning model (problems of students) are much better, because in the learning process with this model students are directed to do several experiments repeatedly. This experiment that is conducted repeatedly and independently aims to formulate and test hypotheses (PBL syntax), so as to foster student activity in asking questions and communicating the knowledge they have to their friends. Teachers who act as facilitators in problem based learning make students learn independently so as to foster student activity to explore more deeply their knowledge. In addition, the problem based learning model which is a learning model that trains students to find their own concepts based on real problems from life with inquiry skills (science process skills) forms a better and lasting concept of students' knowledge.

The data of this research are in line with the results of the research by Hardiyanti [5] which stated that the application of problem based learning models contained differences in $\mathrm{N}$ gain of science process skills by 0.71 and in the control class (lecture and discussion methods) $\mathrm{N}$ - gain of 0.52 . This is because PBL model facilitates students to construct their own knowledge from beginning to understand the existence of a problem to solve the problem. The influence of the problem based learning model on science process skills in this research is also in line with the research of Tasoglu and Bakac [17] with the study about PBL method is more effective than TTM on students' conceptual development and science process skills positively in 1th class of Department of Physics Teaching in Dokuz Eylül University in Turkey. Keil \& Jennifer's [8] research states that the value of students' scientific process skills tests with problem-based learning is very good. This is because the problem based learning model of learning starts 
from students realizing a problem and then students process the problem to be solved through several experiments so that students' independence is very instrumental in the problem based learning model. Akinoglu and Tandogan [2] said that the implementation of problem-based active learning model had positively affected students' academic achievement and their attitudes towards the science course. It was also found that the application of problem based active learning model affects students conceptual development positively and keeps their misconceptions at the lowest level.

\section{CONCLUSIONS}

Based on the findings of the research and analysis conducted by the researcher, several conclusions were obtained, including: There is a significant influence on the problem based learning model (problem of students) toward science process skills in grade $\mathrm{V}$ students. The science process skills of students who are taught with the PBL model (problem of students) with an average of 87.60 , with PBL model (problem of teacher) average of 82.95 , and direct instruction with an average of 78,35 .

\section{REFERENCES}

[1] Akcay. B, Problem-based learning in science education, Journal of Turkish Science Education, vol. VI,p. 26-36, 2009.

[2] Akonoglu, O and Tandogan, R. The Effects of Problem-Based Active Learning in Science Education on Students' Academic Achievement, Attitude and Concept Learning. Eurasia Journal of Mathematics, Science \& Technology Education, vol. 1, p. 71-81, 2007.

[3] Aunurrahman. Belajar dan Pembelajaran. Bandung: Alfabeta. 2012.

[4] Ghozali, I. Aplikasi Analisi Multivariete dengan Program IBM SPSS 23. Jakarta: Wahana Komputer, 2014.

[5] Hardiyanti, PC., Wardani \& Nurhayati. Keefektivan Model Pembelajaran Berbasis Masalah Untuk Meningkatkan Keterampilan Proses Sains. Jurnal Inovasi Pendidikan Kimia, vol. 1, p.1862-1671, 2017.

[6] Hardiyanto., Setyo \& Arjono. Pengaruh Model Pembelajaran Berbasis Masalah dan Ekspositori dengan Keterampilan Proses Sains Terhadap Hasil Belajar Fisika Siswa Kelas VIII MTs Negeri 1 Mataram Tahun Ajaran 2014/2015. Jurnal Pendidikan Fisika dan Tekhnologi.vol. IV, p.249-256, 2015.

[7] Hergenhan, B \& Olson. Theories of Learning. Jakarta: Kencana Prenada media Group, 2014.

[8] Keil., Chris., Haney., Jodi., Zoffel., \& Jennifer. Improvements in Student Achievement and Science Process Skills Using Environmental Health Science Problem-Based Learning Curricula. Electronic Journal of Science Education. Vol. I, p.1-18, 2009.

[9] Roza, B., Hasruddin \& Syahmi. Pengaruh Pembelajaran Berbasis Masalah dan Penemuan Terbimbing Terhadap Keterampilan Proses Sains Siswa SMA Negeri 1 Langsa. Jurnal Pendidikan Biologi. Vol. 1, p.249253, 2016.

[10]Rusman. Model Pembelajaran Untuk Guru Profesional. Jakarta: PT. Rajagrafindo Persada, 2016.

[11] Rusman. Pembelajaran Tematik, Teori, Praktek dan Assessment. Jakarta: PT. Rajagrafindo Persada, 2015.

[12] Said., Rahmini \& Rusmini. Peranan Model Pembelajaran Berbasis Masalah terhadap Keterampilan Proses Sains Kelas VIII SMP Negeri 1 Tellu-Limpue Kabupaten Sidenreng Rappang. Jurnal Pendidikan Fisika. Vol. III, p.226-232, 2013.

[13] Saniman., Bukit, N., \& Mariati P. Effect of Problem Based Learning Models and Understanding of Physics Concepts on Student Learning Outcomes. Tabularasa Journal. Vol. II, p. 34-39, 2015.

[14] Sanjaya. Strategi Belajar Berbasis Standard Proses Pembelajaran. Jakarta: Kencana Prenadamedia Group, 2013.
[15] Sanjaya. Model Pembelajaran. Jakarta: Bumi Aksara. 2015

[16] Suharsimi, A. Prosedur Penelitian. Jakarta: Rineka Cipta, 2014.

[17] Tasoglu., Aslihan., Kartal., Bakac., \& Mustafa. The effects of problem based learning and traditional teaching methods on students' academic achievements, conceptual developments and scientific process skills according to their graduated high school types.Procedia Social and $\begin{array}{llll}\text { Behavioral Sciences, vol. II, p.2409-2413, } 201 & \end{array}$ 
